\title{
LEGAL REGULATION OF SOCIAL NETWORKS: NECESSITY AND PROSPECTS (ON THE EXAMPLE OF THE REPUBLIC OF UZBEKISTAN)
}

\author{
Khujayev Shokhjakhon Akmaljon ugli \\ Head of Intellectual property law department, PhD in law, Tashkent state University of Law, Tashkent, Uzbekistan. \\ E-mail: sh.xujayev@tsul.uz
}

\begin{abstract}
This article analyzes the scientific and practical issues of regulation of social networks, in particular, the issues of the need for legal regulation of social networks in the context of digital development of the Republic of Uzbekistan. Scientific novelty of research consists in the fact that the article was first explored the issues of forming legal basis of social networks, the regulation of relations in social networks, protection of rights and freedoms, interests of legal entities and the state of information security. The study is considered important from the point of view of the fundamental study of legal relations in social networks in Uzbekistan. The practical significance of this article is the possibility of using the results obtained in the course of the study in the implementation of the tasks provided for in the Laws of the Republic of Uzbekistan «On Informatization», «On the principles and guarantees of freedom of Information», «On Guarantees and freedom of access to information».
\end{abstract}

Keywords:

social network, internet, legal regulation, Uzbekistan, cyber law, messengers, user.

Article Received: 18 October 2020, Revised: 3 November 2020, Accepted: 24 December 2020

\section{Introduction}

Today, in the context of globalization, the virtualization of relations and digitalization of almost all forms of activity have become an irreversible and integral element of our life. Virtual space, especially social networks, expanding the possibilities of relationships between members of society, created a new form of public relations in the World Wide Web. Today, it is impossible to imagine everyday life without social networks.

According to data from the analytical companies We Are Social and Hootsuite, the audience of social networks reaches 3.96 billion in the first half of 2020 . people, or $51 \%$ of the world's population [1]. At the same time, over the past year, the number of social media users has grown by $10.5 \%$, with about a million people registering on various platforms every day. Of these, $99 \%$ access social networks via smartphones. According to the official data of the Ministry for the Development of Information Technologies and Communications, as of December 2020, more than 22.5 million Uzbek citizens are covered by the Internet in Uzbekistan
[10]. According to Datareportal, at the beginning of 2020 , the number of users of social networks was 3.2 million people [2].

Starting from ordinary citizens-users, ending with government agencies, social networks are becoming the most popular platform for interaction. The increasing influence of social networks on the consciousness of people, on the one hand, indicates their convenience and efficiency for members of society, but on the other hand, significantly increase the risk of negative use of social networks by turning them into a «tool» for intruders and other destabilizing elements. In turn, the absence of any regulatory mechanisms, in particular legal norms regarding social networks, requires the adoption of timely and adequate response measures on the part of the state. The ongoing COVID-19 coronavirus pandemic makes it even more clear that the delay in taking measures to regulate social networks can lead to various kinds of problems of a political, social and economic nature.

\section{Methods}

The study used various methods of the theory and practice of jurisprudence. In particular, 
the method of analysis is the conditional consideration of social networks as objects of legal research by separately separating the relations subject to protection, the participants in the relations, the status of the social networks themselves and users (bloggers) into separate parts, highlighting their main or essential features, on the basis of which a certain proposal is developed; the method of synthesis is the study of various components of relations that arise in social networks by combining their parts; The critical-legal method of analogy is to test the theoretical provisions of the legal status of social networks, freedom of access to information and the liberalization of the information environment by the criteria of fairness, objectivity, sufficiency, as well as the need to prevent excessive freedom that violates the rights and legitimate interests of others.

The critical analysis of the legislation made it possible to draw the following conclusions about the priorities for improving legislation in the field of legal aspects of social networks:

inventory of national legislation for implementation, bringing it in line with international standards and best foreign practices;

determination of the legal status of social networks and their subjects, the category of legal relations requiring legal regulation, by preparing proposals for the development of legal norms and amendments and additions to certain legislative acts of the Republic of Uzbekistan;

creating a conceptual framework for the regulation of social networks, ensuring information security, developing standards for the regulation and filtering of content in social networks;

elimination of legal gaps and conflicts in legislation that hinder the effective functioning of the system for protecting the rights and legitimate interests of individuals, society and the state in social networks, ensuring the effectiveness of measures of responsibility for offenses in social networks.

\section{Discussion}

The implementation of measures on the legal regulation of social networks corresponds to the goals of the Laws of the Republic of Uzbekistan «On Informatization», «On Principles and guarantees of Freedom of Information», «On Guarantees and freedom of access to Information», the Strategy of Action on the five priority areas of development of the Republic of Uzbekistan in 2017 - The objectives of the Comprehensive Program for the further Development of national content in the world information network Internet for the period 20192021 [3] for the continuous study of trends in the development of the global and national segment of the world information network Internet, the formation of proposals for improving the mechanisms for the development of national content of the world information network Internet and improving the regulatory framework.

Meanwhile, the need for the development of science, education and the digital economy demonstrates the importance of developing national content in domestic social networks and expanding its presence in foreign information resources of the world information network Internet, improving the activities of social networks and messengers in Uzbekistan.

At the same time, the legal regulation of social networks will also solve the problems of ensuring information security in the context of globalization. Timely and proper response to the facts of offenses and threats, the dissemination of false information in social networks will ensure the creation of the necessary conditions and guarantees of free access to information, protection of privacy, protection from illegal information and psychological influences.

Preventing illegal information and psychological influence on public consciousness, manipulating it, creating a system to counteract information expansion aimed at deforming national identity, separating society from historical and national traditions and customs, destabilizing the socio-political situation, violating interethnic and interfaith harmony require the early adoption of the legal framework of social 
networks in the Republic of Uzbekistan. The existence of a regulatory framework provides an opportunity to monitor content in social networks, regulate and filter false information.

To regulate the legal aspects of social networking in the context of globalization and virtualization is the creation of an effective and adequate mechanism of legal regulation, social networking, emerging in her relations with the realities, the formation of a conceptually new approach to virtual relations, in particular social networks as the new phenomenon of the modern digital development, search evidence-based and practice oriented proposals for solving problems in regulation and social networking activities of their users.

At the same time, the analysis of the current legislation shows that there are no norms regarding the regulation of the national segment of the Internet and social networks, and the existing general norms are insufficient for optimal solutions to problems in social networks regulation of civil relations, protection of the individual, society and the state, ensuring information security. Having analyzed the current legislation of the Republic of Uzbekistan, as well as based on the practical experience of developed countries [4], we can conclude that today's legislation does not reflect the features of virtual legal relations, modern cyber law. Moreover, the status of social networks, their users and owners is not defined, legal relations in social networks are not regulated, there is no practical mechanism for protecting privacy, personal data, business reputation of companies, and state security. Tazhke does not regulate the procedure for resolving disputes, including international commercial disputes [5]. Thus, a scientific study of the legal aspects of social networks is necessary.

It is necessary to take into account the fact that the theoretical support should clearly define the general principles of legal regulation of social networks, the conceptual framework for ensuring information security, which should be implemented in practice in the development of draft laws. In our opinion, in this regard, it is necessary to take into account the experience of national authors - S.Gulyamov [6], I.Rustambekov [7], A.Rasulev [8].

It should be noted that legal regulation should take into account the entire national legal system in order to create a complete and fully harmonized set of rules that ensure both proper regulation and freedom of access to information.

\section{Research and Analysis}

The legal aspects of social networks are a complex of relations, the regulation of which is complex and multifaceted, and their scientific research is relevant.

First, the legislation of the Republic of Uzbekistan does not determine the legal status of social networks, their owners and users. The issues of regulating the virtual space are generally reflected only in the norms of the Laws of the Republic of Uzbekistan «On Informatization», «On the principles and guarantees of Freedom of Information», «On Guarantees and freedom of access to information» [3]. However, these legal acts do not provide for mechanisms for regulating social networks and their subjects (the texts of the laws do not contain the concept of «social networks»). A clear definition of the legal status of social networks will make it possible to distinguish them from the mass media, electronic platforms for certain types of activities (ecommerce, provision of services), and interaction between various entities (circulation through social networks).

Secondly, social networks have become a widely popular platform for carrying out various types of activities. So, social networks become an excellent environment for trade and commercial activities (various types of Telegram bots that accept orders for the delivery of food and other goods). Many business structures (entrepreneurs, companies) actively conduct their activities through social networks, in particular in the Telegram messenger (for example, the food ordering service EVOS, Street 77 burger), Instagram. 
In turn, for government agencies and organizations, the work in social networks has become the most important indicator of their openness and transparency. Social networks have become a convenient platform for dialogue with the population, working with appeals of individuals and legal entities. The information policy of state bodies and organizations is now evaluated not by the availability of information in the official websites, but by the speed of the information provided in social networks. By itself, the presence of an official page of state bodies in social networks already indicates that the social network has ceased to be a platform for personal correspondence and communication between people. Today, the social network is an important platform for society and the state. Modern users look at the social network as a platform for obtaining official information.

According to the UReport survey, the most popular sources of information about changes in legislation and new laws used by the survey participants today are the Telegram channels of the Ministry of Justice (34\%) and the Internet media $(22 \%)$. At the same time, social networks are the most popular source among all age groups of respondents [11].

The presence of various types of relations on the Internet allows us to distinguish both civil legal relations (the provision of services and the delivery of goods through social networks) and public relations (appeals to state bodies, information policy, etc.). Without any doubt, the unsettled nature of these relations entails:

the lack of proper control over traditional relations (for example, taxation of the provision of services, delivery of goods through social networks) is problematic because it is difficult to maintain quantitative and qualitative accounting of the taxable object in this format of activity);

the chaotic nature of relationships, the formation of a sense of irresponsibility and impunity (the lack of legal norms leads to problems in bringing to justice), as a result of which there is a fact of violation of the rights and freedoms of the individual in the virtual space.
Third, social networks, unfortunately, have become a place of violation of the rights and interests of the individual, society and the state. Increasingly, offenses and other illegal actions are committed in social networks. It is not for nothing that the world community is interested in creating an effective mechanism to counter threats in social networks. The conditions of the pandemic showed an increase in various financial frauds and fraudulent operations.

According to the gazeta.ru during the coronavirus pandemic, the number of calls from fraudsters in Russia increased by $200 \%$. In the first half of 2020, fraudsters stole 4 billion rubles from the accounts of bank customers [12].

The virtual nature of relations in social networks expands the range of violations, often offenses in social networks are committed on the territory of several States, which indicates the need to take measures to respond to these offenses.

One of the key problems is the problem of regulating the activities of bloggers. According to the Law of the Republic of Uzbekistan «On Informatization», a blogger is defined as an individual who places publicly available information of a socio-political, socio-economic and other nature on their website and / or website page on the world information network, including for discussion by information users. As can be seen from the definition, there are no specific requirements for a blogger, which indicates that everyone can become a blogger. The law «On Informatization» prohibits a blogger from calling for a violent change in the existing constitutional order, territorial integrity of the Republic of Uzbekistan, promoting war, violence and terrorism, as well as ideas of religious extremism, separatism and fundamentalism, disclosing information that constitutes state secrets or other secrets protected by law, spreading information that incites national, racial, ethnic or religious hostility, as well as discrediting the honor and dignity or business reputation of citizens, allowing interference in their private lives, promote narcotic drugs, psychotropic substances and 3584 
precursors, pornographic materials, as well as perform other actions that entail criminal and other liability in accordance with the law. However, there are no effective measures for bringing to justice and preventive control over the prevention of such actions in the legislation. This, in turn, entails the expansion of

According to a survey conducted by UReport, almost half (49\%) of respondents believe that there is a problem with fake news in Uzbekistan. Respondents suggested strengthening state control/ verification/supervision over social networks, blocking access to sources that publish fake news, especially in social networks [11].

At the same time, there are problems with Internet harassment in social networks, which negatively affect the consciousness of people, in particular young people. Dubbed «cyberbullying», this negative phenomenon has an impact on the minds of young people. Although the Law of the Republic of Uzbekistan «On the protection of children from information harmful to their health» provides for the protection of children from negative information, the provisions of the Law do not provide for the specifics of protecting children in the virtual space, filtering information in social networks. Cyberbullying is characterized by systematic and purposeful behavior, and the inability to identify the perpetrators. Also, the consequences of cyberbullying are expressed in a violation of the mental state and psychological balance, sometimes suicide or an attempt on it.

According to the study Mail.ru While more than $70 \%$ of Russian schoolchildren have been bullied, harassed or insulted on the Internet, a total of $58 \%$ of Russians have experienced online bullying. At the same time, about $76 \%$ of teenagers do not tell their parents about bullying [13].

The next important aspect is expressed in the regulation of the protection of privacy and personal data, preventing the dissemination of false and offensive information in social networks. Today, you can find many examples of illegal use of personal data of celebrities in their accounts and pages on social networks.
The State Unitary Enterprise «Center for Cybersecurity» noted that there are 40,640,449 freely available lines in the Telegram messenger around the world, of which 50,062 lines belong to the numbers of Uzbek mobile operators. A preliminary study showed a match of more than $50 \%$ of the compromised data, which indicates the relevance of the threat to the Uzbek segment of Telegram messenger users.

The urgency of this problem is particularly evident in the current global pandemic of the COVID-19 coronavirus infection caused by the SARS-CoV-2 coronavirus. In this regard, a quick and adequate response to these threats and the adoption of preventive measures in the form of legal norms regulating this area are of key importance.

\section{Conclusion}

In connection with the above, the following important issues should be highlighted in the legal regulation of social networks: the

legal status of social networks and their owners, users;

regulation of relations arising in social networks;

problems of protecting the rights and interests of individuals, society and the state in social networks, countering offenses.

Solving the problems of regulating the activities of social networks is of both theoretical and practical importance. The presence of complex problems indicates the importance of theoretical research of the essence of social networks within the framework of a complex system of cyber law, since traditional branches of law (civil law, administrative law) are not fully able to ensure the effectiveness of regulation and proper protection of the rights and freedoms of the individual, society and the state. While the legislation regulates some aspects of these problems in various legal acts, the lack of a comprehensive approach to social networks leads to the emergence of multi-vector problems.

It is necessary to take into account the fact that information and communication technologies are already developing rapidly in Uzbekistan, and 
digitalization is becoming the ultimate goal of reforming various state spheres (judicial proceedings, public services). Therefore, the delay in regulating social networks will hinder the development of the digital economy.

Therefore, social networks should be studied through the prism of legal norms in the context of modern realities.

Thus, an effective legal basis for regulating relations in social networks is an objective necessity that determines the state policy in the information sphere in the coming decades. What follows is the need to regulate the legal aspects of social networks in the context of globalization and virtualization: determining the legal status of social networks, regulating legal relations in social networks, protecting the subjects of virtual relations.

As part of the legislative changes, it will be necessary to conduct research in the following main areas. First, a comparative legal analysis and study of the best foreign experience in the implementation of the legal mechanism for regulating social networks. Secondly, the inventory of the legislation of the Republic of Uzbekistan, the development of conceptual proposals for the development of norms, as well as amendments and additions to the current legislation of the Republic of Uzbekistan.

\section{References}

[1] https://wearesocial.com/digital-2020.

[2] https://datareportal.com/reports/trackingict-trends-using-social-media-data.

[3] https://lex.uz/ (National database of legislation of the Republic of Uzbekistan).

[4] Yakubova, I. «CIVIL-LAW PROTECTION OF HONOR, DIGNITY AND BUSINESS REPUTATION IN THE CIVIL LEGISLATION OF
UZBEKISTAN AND JAPAN.» Review of law sciences 3 (2018).

[5] Мукумов, Бобур. «ОЦЕНКА РЕГУЛИРУЮЩЕГО ВОЗДЕЙСТВИЯ НОРМАТИВНО-ПРАВОВЫХ АКТОВ НА ПРЕДПРИНИМАТЕЛЬСКУЮ ДЕЯТЕЛЬНОСТЬ В УСЛОВИЯХ ПАНДЕМИИ КОРОНАВИРУСА (НА ПРИМЕРЕ

ТОРГОВОПРОМЫШЛЕННОЙ ПАЛАТЫ РЕСПУБЛИКИ УЗБЕКИСТАН).» Review of law sciences 2 (2020).

[6] Said, Gulyamov, and Rustambekov Islambek. «RECOMMENDATIONS ON THE PREPARATION AND PUBLICATION OF SCIENTIFIC ARTICLES IN INTERNATIONAL PEER REVIEWED JOURNALS.» Review of law sciences 4 (2020).

[7] Rustambekov, Islambek. «Some Aspects of Implementation of Private International Law Principles in Civil Code of Uzbekistan.» Available at SSRN 3642669 (2020).

[8] Rasulev, A. K. «Improvement of criminal-legal and criminological measures of fight against crimes in the sphere of information technologies and safety: Doctoral (DSc) dissertation abstract on legal sciences.» (2018).

[9] Rustambekov, Islambek. «Some Aspects of Development of Private International Law in the CIS Countries.» LeXonomica 12.1 (2020): 27-50.

[10] https://mitc.uz/ru/pages/publications

[11] https://uzbekistan.ureport.in/story/349/

[12] https://www.gazeta.ru/social/2020/11/09/ 13354063.shtml

[13] https://externat.foxford.ru/poleznoznat/kiberbulling-detej-i-podrostkov 